\title{
A Study on Comfort Properties of Banana / Cotton Blend Woven Fabrics
}

\section{Hafez S. Hawas}

Lecturer at Spinning, Weaving \& Knitting dept., Faculty of Applied Arts, Helwan University, Egypt.

\author{
\begin{tabular}{l|l|l|l|} 
Submit Date: 2020-07-08 09:32:20 & Revise Date: 2021-01-01 12:00:00 | Accept Date: 2021-01-02 02:14:56
\end{tabular}
}

DOI: 10.21608/jdsaa.2021.35112.1069

Keywords:

Banana fiber

Comfort properties

Woven fabrics

Sustainability

Apparel fabrics

\begin{abstract}
:
This research is concerned with studying the effect of banana blended ratio and weave structure on comfort properties of produced apparel fabrics. Banana /cotton blend \& 100\% cotton yarns were used as weft materials with three different weave structures (plain 1/1, twill 2/2 and satin 4) for weaving nine samples.

The experiment demonstrated that there is a direct relationship between the percentage of banana fibers in produced samples and air permeability, fabric stiffness and water vapour permeability (WVP). Whereas the weave structure, satin 4 has recorded the highest rates in all evaluated comfort properties
\end{abstract}




\section{INTRODUCTION:}

Today, comfort has become a major quality criterion of textile materials [1]. it has been given a prime importance due to the customer acceptability of textile product, largely depending on the comfort aspects which involve thermal properties, air permeability, and water vapor permeability [2]. Comfort is a complex subject and is a result of numerous parameters interactions; as physical, psychological and physiological

Fabric comfort means understanding the relationship between fiber material, yarn structure, fabric structure, transmission characteristics (air, heat and moisture) and tactile aspects of textile materials [3]. The fabric material is considered the most important parameter that determines the comfort of cloth [4]. There is a general agreement that the permeability of water vapour and air through the fabric are probably the most important factors in fabrics comfort [5].

Textile fibers are mainly divided into two groups; natural and synthetic fibers [4]. In recent years, environmental awareness has been increased so as a result the industry sector is trying to decrease the usage of petroleum-based fuels and products. This leads to investigate the need to environmentally friendly, sustainable materials to replace synthetic fibers [6].

Natural fibers are generally believed to provide better comfort sense more than manmade fibers [4]. Natural fibers have been used as an alternative over synthetic fibers due to their features such as recyclability, biodegradability, renewability, no health hazard, and high mechanical properties $[7,8,9]$. It is gaining Widespread as textile material for many industrial applications, technical textiles, composites, pulp and paper [10]. In addition, to traditional applications as garment, upholstery and curtains.

Nowadays, the growing importance of eco-friendly fabrics lead to an increase in searching for more efficient material which has a significant impact on the development of new products [11]. one of this new fiber is banana fiber which has been recognized for all its good qualities and now its application is increasing such as apparel garments and home furnishings [7].

Banana fiber is a bast fiber which is obtained from the pseudo-stem of the plant. Fibers obtained are lustrous and fine with relatively good mechanical properties. After the fruits are harvested for two to four times a year, the stem of banana plant is a major waste mate- rial which creates disposal problems $[12,13,14]$. Low percentage of this stems have been dedicated to cattle feed [15]. Banana fiber can be extracted from banana stem by many different methods as; manual, mechanical, chemical and biological methods [12].

Utilization of agricultural residues may have significant benefits for the environment and the agricultural community by preventing incineration on the field and by providing extra value to agricultural crops [16]. In Egypt, banana is one of the oldest cultivated plants and fruit crops [17,18]. Between 1969 and 2018, bananas production of Egypt grew substantially from 91,000 to 1.39 million tonnes as shown in below figure (1). The word banana comes from the Arabic language and means 'finger' [8].

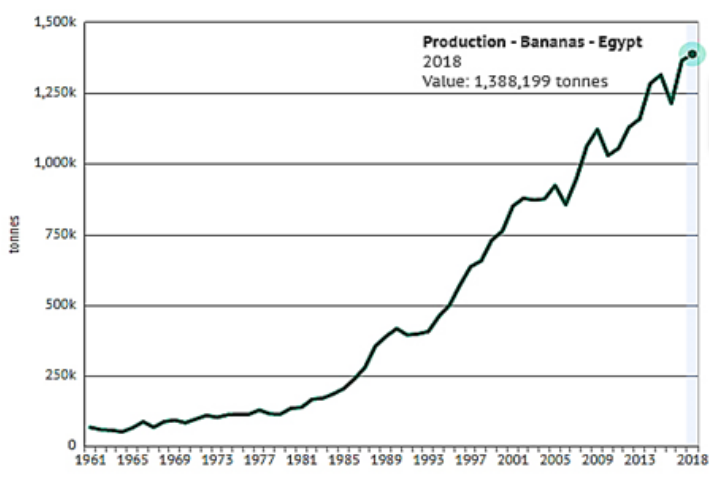

Fig. (1) Production of banana in Egypt (million tonnes/year) [19]

The main objective of this paper is studying the effect of banana fiber ratio on the comfort properties of produced apparel fabrics as; air permeability, water vapour permeability and fabric stiffness.

\section{Materials and Methods:}

The present work is concerned with studying the comfort properties of banana/cotton produced fabrics with three different blended ratios.

2.1. Warp \& Weft materials

Nine samples were produced, using dobby weaving machine with the operational specifications as shown in table (1). The warp material for all produced samples was $100 \%$ cotton, with linear density of $50 / 2 \mathrm{Ne}$ and the warp density was $36 \mathrm{ends} / \mathrm{cm}$, On the other hand, weft materials were $100 \%$ cotton yarn and blended yarn (banana/cotton), both of them with linear density of 20/1 Ne, and the number of picks per centimeter were 21 picks $/ \mathrm{cm}$. Blend yarn $(50 \%$ banana fiber: $50 \%$ Cotton fiber) was supplied by Banfab co. Ltd, India 
Table (1) specifications of produced samples

\begin{tabular}{|c|c|c|c|c|c|}
\hline $\begin{array}{c}\text { Sample } \\
\text { No. }\end{array}$ & $\begin{array}{c}\text { Fabric } \\
\text { structure }\end{array}$ & $\begin{array}{c}\text { Arrangement } \\
\text { of Wefts }\end{array}$ & Weft Ratio & Ends/cm & Picks/cm \\
\hline 1 & Plain1/1 & \multirow{3}{*}{1 Blend: 1 Cotton } & \multirow{3}{*}{$25 \%$ Banana: $75 \%$ Cotton } & \multirow{9}{*}{36} & \multirow{9}{*}{21} \\
\hline 2 & Twill $2 / 2$ & & & & \\
\hline 3 & Satin 4 & & & & \\
\hline 4 & Plain1/1 & \multirow{3}{*}{2 Blend: 1 Cotton } & \multirow{3}{*}{ 33.4\% Banana: $66.6 \%$ Cotton } & & \\
\hline 5 & Twill $2 / 2$ & & & & \\
\hline 6 & Satin 4 & & & & \\
\hline 7 & Plain1/1 & \multirow{3}{*}{$100 \%$ Blend } & \multirow{3}{*}{$50 \%$ Banana: $50 \%$ Cotton } & & \\
\hline 8 & Twill 2/2 & & & & \\
\hline 9 & Satin 4 & & & & \\
\hline
\end{tabular}

* Note: calculations of weft ratio for produced fabrics [20].

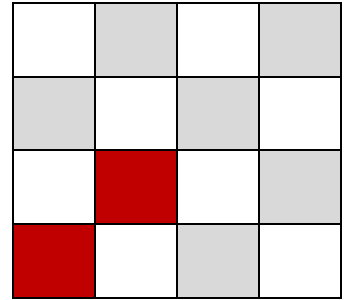

Plain 1/1

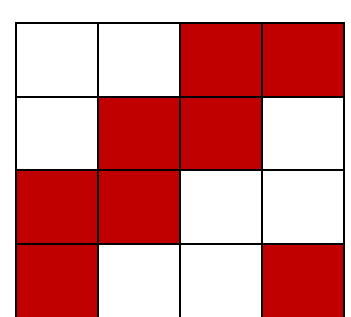

Twill 2/2

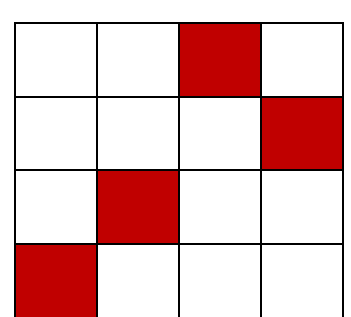

Satin 4
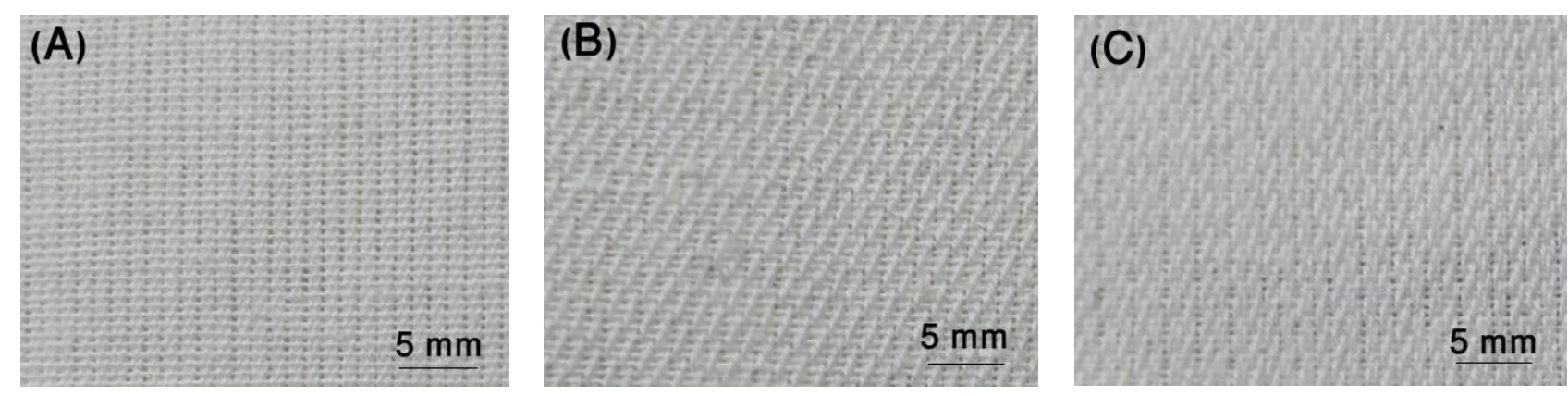

Fig. (3) Digital photos of produced banana / cotton fabrics; $(A)$ sample 7 - plain 1/1, $(B)$ sample 8 - twill 2/2, $(C)$ sample 9 - satin 4 (Back side of fabric)

\subsection{Laboratory Testing}

Many different tests were carried out on produced samples to evaluate the comfort properties.

\subsubsection{Fabric Areal Density Test}

This test was carried out on samples according to the American Standard Specification of (ASTM D3776:09) [21]

\subsubsection{Thickness test}

This test was carried out by using Mitutoyo thick- ness digital gage no. 7301 produced by Turlock Japan company according to the American Standard Specification of (ASTM D1777 - 96 (2015)) [22]

\subsubsection{Air permeability Test}

This test was carried out by using The Digital Air Permeability Tester M021A (SDL ATLAS) according to the American Standard Specification of (ASTM D737 - 04 (2012)) [23] 


\subsubsection{Stiffness Test}

This test was carried out by using (Digital Pneumatic Stiffness Tester) according to the American Standard Specification of (ASTM D4032-08) [24]

\subsubsection{Water vapour permeability (WVP)}

This test was carried out by using cup method accord- ing to British Specification of (BS 7209- 1990) [25]

\section{Result and Discussion:}

This part is concerned with studying the effect of the research variables on the produced samples properties. The following table (2) shows the results of tests applied to the produced Banana / cotton fabrics.

Table (2) Produced fabrics testing results

\begin{tabular}{|c|c|c|c|c|c|c|c|}
\hline & \multicolumn{2}{|c|}{ Variable Parameter } & \multicolumn{5}{|c|}{ Results } \\
\hline 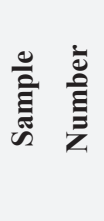 & 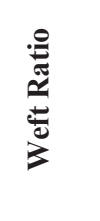 & 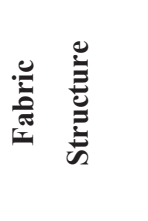 & 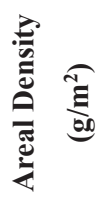 & 崖 & 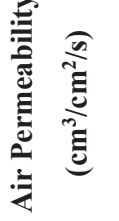 & 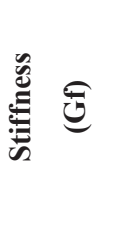 & 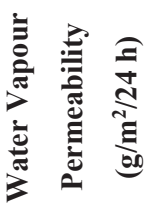 \\
\hline 1 & \multirow{3}{*}{ 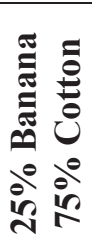 } & Plain1/1 & 1450 & .34 & 85.7 & 180.5 & 457 \\
\hline 2 & & Twill 2/2 & 143.7 & 0.43 & 139 & 136.6 & 506 \\
\hline 3 & & Satin 4 & 142.2 & 0.4 & 141.5 & 121 & 602 \\
\hline 4 & \multirow{3}{*}{ 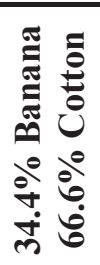 } & Plain1/1 & 143.8 & 0.35 & 102.5 & 175.4 & 537 \\
\hline 5 & & Twill 2/2 & 142.7 & 0.43 & 138.7 & 128.3 & 570 \\
\hline 6 & & Satin 4 & 141.3 & 0.41 & 141.8 & 117.3 & 635.2 \\
\hline 7 & \multirow{3}{*}{ 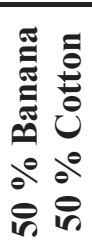 } & Plain1/1 & 141.7 & 0.34 & 107 & 165 & 558 \\
\hline 8 & & Twill 2/2 & 138.9 & 0.42 & 143.3 & 102 & 636.5 \\
\hline 9 & & Satin 4 & 137.5 & 0.4 & 148 & 93.8 & 663 \\
\hline
\end{tabular}

\section{3-1: Fabric areal Density:}

Table (2) and figure (4) shows the results of areal density test carried out on the produced samples using the following parameters: three different arrangement for weft picks \& three different weave structures.

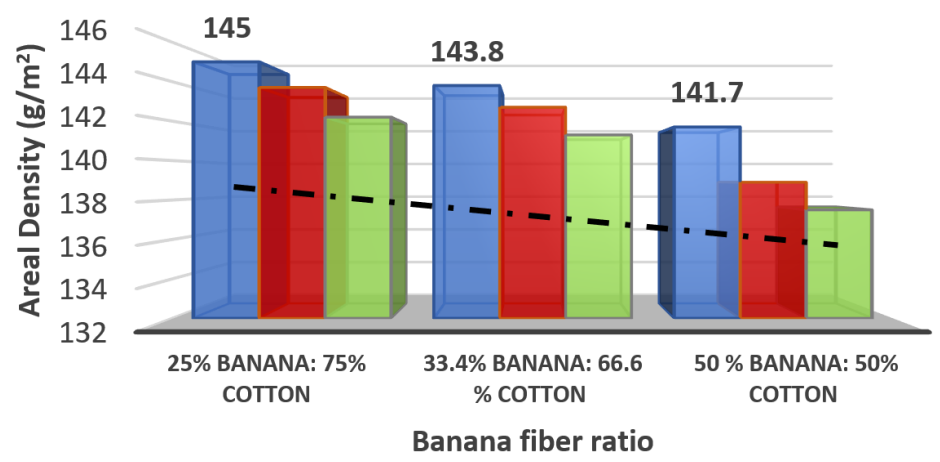

$\square$ plain 1/1 $\quad$ twill 2/2 $\square$ satin 4

Fig. (4) Effect of banana fiber ratio \& weave structure on fabric areal density. 
Table (3) Regression equation and quadratic coefficient for the effect of banana fibre ratio on fabric areal density for produced samples.

\begin{tabular}{|c|c|c|}
\hline Weave structure & Regression equation & $\mathbf{R}^{\mathbf{2}}$ \\
\hline Plain 1/1 & $\mathrm{y}=-13.123 \mathrm{x}+148.24$ & 0.999 \\
\hline Twill 2/2 & $\mathrm{y}=-19.717 \mathrm{x}+148.89$ & 0.9812 \\
\hline Satin 4 & $\mathrm{y}=-19.374 \mathrm{x}+147.33$ & 0.9761 \\
\hline
\end{tabular}

Where, $\mathrm{y}=$ Areal density (weight) $\quad \mathrm{x}=$ Banana fibre ratio

\section{3-1-1: Effect of banana fiber ratio on fabric ar-} eal density:

From tables (2\&3) and figure (4) it can be seen that, there is an inverse relation between the areal density and the ratio of banana fibres in the produced fabrics. That is due to the density of banana fiber is less than cotton, where the density of banana is 1.35 and the density of cotton 1.54 [20].

3-1-2: Effect of weave structure on fabric areal density:

It can be noticed from figure (4) that plain $1 / 1$ has recorded the high rates of fabric weight followed by twill $2 / 2 \&$ satin 4 respectively. This is due to decreases the float length in weave structure lead to an increase in the number of intersections per unit area in the produced fabrics and increase the yarns crimp, as a result the fabric areal density increased.

\section{3-2: Fabric thickness:}

Table (2) and figure (5) shows the results of thickness test carried out on the produced samples using parameters mentioned before.

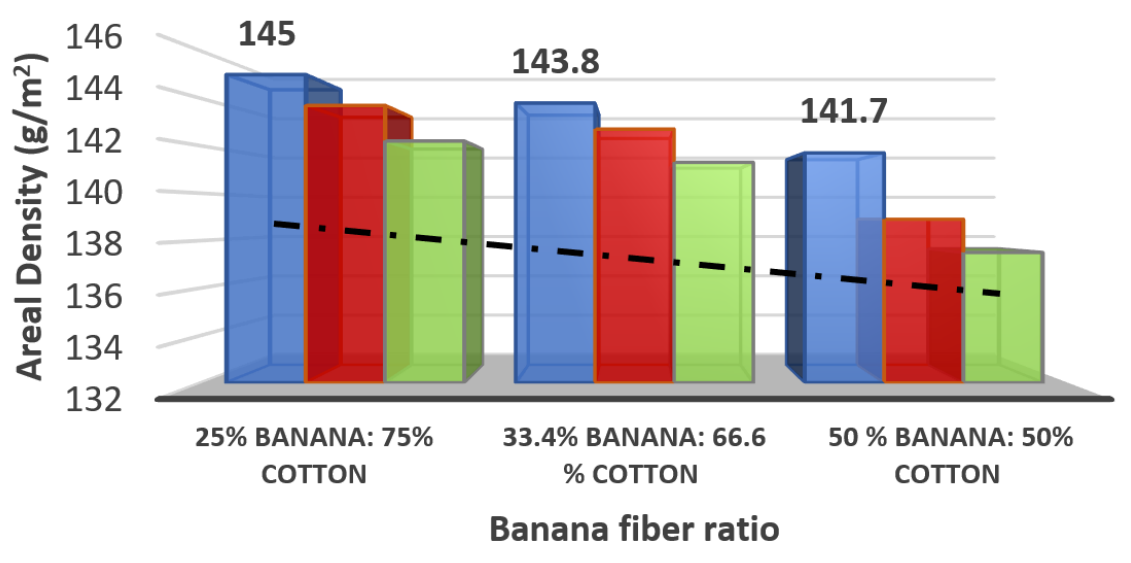

plain 1/1 $\quad$ twill 2/2 $\square$ satin 4

Fig. (5) Effect of banana fiber ratio \& weave structure on fabric thickness.

Table (4) Regression equation and quadratic coefficient for the effect of banana fibre ratio on fabric thickness for produced samples.

\begin{tabular}{|c|c|c|}
\hline Weave structure & Regression equation & $\mathbf{R}^{\mathbf{2}}$ \\
\hline Plain 1/1 & $\mathrm{y}=-0.0084 \mathrm{x}+0.3464$ & 0.0346 \\
\hline Twill 2/2 & $\mathrm{y}=-0.0428 \mathrm{x}+0.4421$ & 0.891 \\
\hline Satin 4 & $\mathrm{y}=-0.0084 \mathrm{x}+0.4064$ & 0.0346 \\
\hline
\end{tabular}

Where, $\mathrm{y}=$ Thickness

$\mathrm{x}=$ Banana fibre ratio 


\section{3-2-1: Effect of banana fiber ratio on fabric} thickness:

From tables (2\&4) and figure (5) it can be seen that this parameter has insignificant effect on the fabric thickness.

\section{3-2-2: Effect of weave structure on fabric thickness:}

From figure (5) it can be observed that, twill $2 / 2$ has recorded the high rates of fabric thickness followed by satin $4 \&$ plain $1 / 1$ respectively. This is owing to weave structures which have a long float length lead to greater fabric thickness than plain weave with a small float length. [26].

\section{3-3: Air permeability:}

Table (2) and figure (6) shows the results of air permeability test carried out on the produced samples using parameters mentioned before.

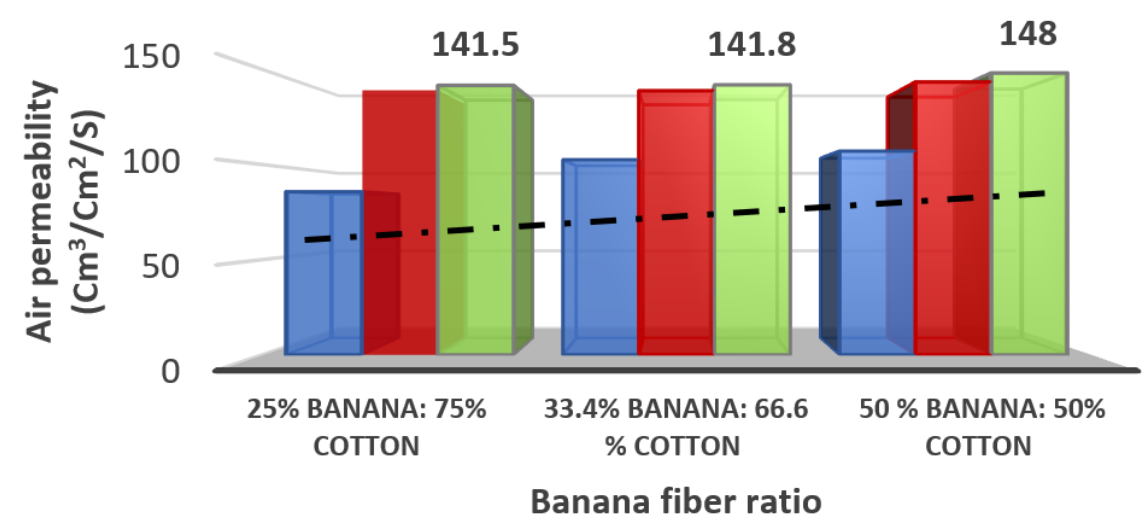

plain 1/1 $\square$ twill 2/2 $\square$ satin 4

Fig. (6) Effect of banana fiber ratio \& weave structure on air permeability.

Table (5) Regression equation and quadratic coefficient for the effect of banana fibre ratio on fabric air permeability for produced samples.

\begin{tabular}{|c|c|c|}
\hline Weave structure & Regression equation & $\mathbf{R}^{\mathbf{2}}$ \\
\hline Plain 1/1 & $\mathrm{y}=77.057 \mathrm{x}+70.557$ & 0.7626 \\
\hline Twill 2/2 & $\mathrm{y}=18.673 \mathrm{x}+133.59$ & 0.8521 \\
\hline Satin 4 & $\mathrm{y}=27.591 \mathrm{x}+133.8$ & 0.9152 \\
\hline
\end{tabular}

Where, $\mathrm{y}=$ Air permeability $\quad \mathrm{x}=$ Banana fibre ratio

\section{3-3-1: Effect of banana fiber ratio on air per- meability:}

From tables (2\&5) and figure (6) it can be seen that, there is a direct relation between the air permeability and the ratio of banana fibres in the produced fabrics. This is due to the yarn which has a high value of hairiness, indicates that more mi- gration fibres covering the fabric surface, so as a result the fabric becomes low porosity and hence the air permeability decreased. As shown in figure (7\&8). In addition to the surface morphology and cross section of banana fiber has porous structure with high surface area [27], which leads to an increase in passing air through the fabric effectively. 
(A)
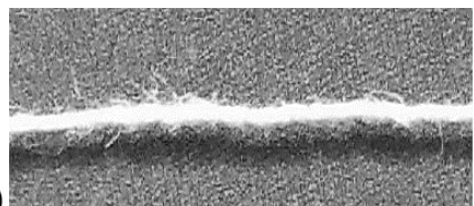

(B)

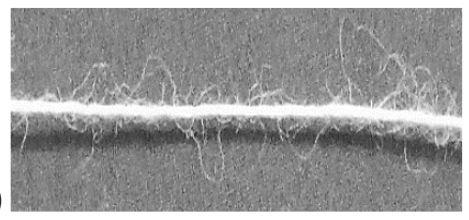

Fig. (7) Illustration of the yarn hairiness: A) Blended yarn (50\% banana: $50 \%$ cotton - with low hairiness), B) $100 \%$ cotton yarn (with high hairiness)

(A)

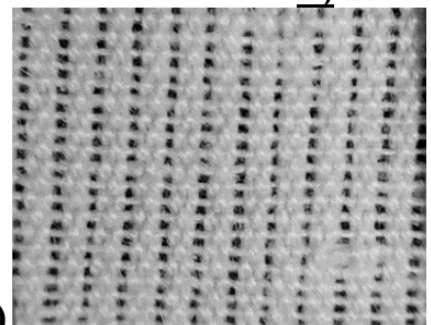

(B)

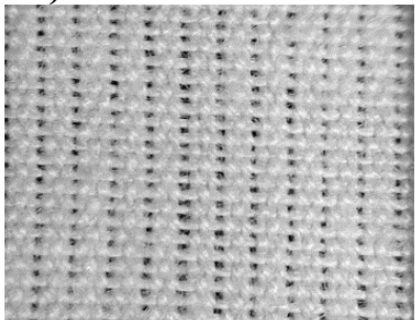

Fig. (8) Illustration of the pore size for produced fabrics: A) sample 7 produced from $50 \%$ banana: $50 \%$ cotton (high porosity), B) sample 1 produced from $25 \%$ banana: $75 \%$ cotton (low porosity)

3-3-2: Effect of weave structure on air permeability:

It can be observed from figure (4) that Satin 4 has recorded the high rates of fabric air permeability followed by twill $2 / 2 \&$ plain $1 / 1$ respectively. This is owing to increases the float length in weave structure means less number of intersections per unit area in the produced fabrics that leads to a fabric will be less compact and inter yarn spacing will be more, which allow the air to pass through more freely [28]. 3-4: Fabric Stiffness:

Table (2) and figure (9) shows the results of fabric stiffness test carried out on the produced samples using parameters mentioned before.

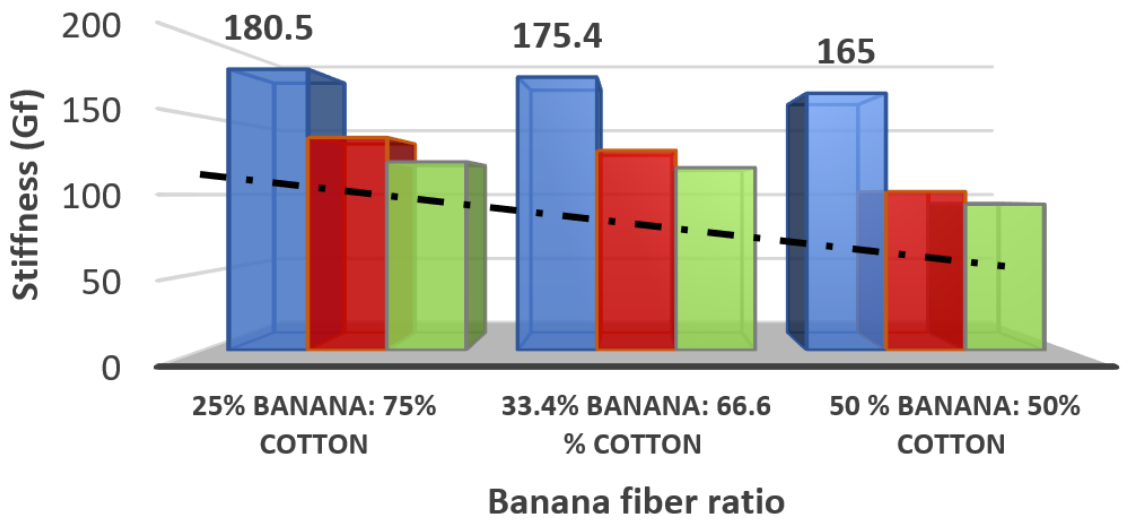

$\square$ plain 1/1 $\quad$ twill 2/2

Fig. (9) Effect of banana fibre ratio \& weave structure on fabric stiffness.

Table (6) Regression equation and quadratic coefficient for the effect of banana fibre ratio on fabric stiffness for produced samples.

\begin{tabular}{|c|c|c|}
\hline Weave structure & Regression equation & $\mathbf{R}^{\mathbf{2}}$ \\
\hline Plain 1/1 & $\mathrm{y}=-62.091 \mathrm{x}+196.07$ & 0.9999 \\
\hline Twill 2/2 & $\mathrm{y}=-141.21 \mathrm{x}+173.32$ & 0.9891 \\
\hline Satin 4 & $\mathrm{y}=-113.39 \mathrm{x}+151.67$ & 0.9563 \\
\hline
\end{tabular}

Where, $y=$ Fabric Stiffness

$\mathrm{x}=$ Banana fibre ratio 


\section{3-4-1: Effect of banana fiber ratio on fabric stiffness:}

Tables (6) and figure (9) represented the relationship between fabrics stiffness and banana fiber ratio as weft material, illustrate that by increasing the banana fiber ratio in weft picks leads to lowest value in fabrics stiffness and vice versa. This is due to the increase in the banana fiber percentage leads to a decrease in area density of produced fabrics as shown in table (2). So as a result, bending resistance of fabrics decreases.

\section{3-4-2: Effect of weave structure on fabric stiff-}

ness:

From figure (9) it can be seen that, satin 4 has scored the low rates of fabric stiffness compared to plain $1 / 1$. This is because of this fact, the Fabrics which have long floats in weave structure can be more flexible. So as a result, the usage of satin weave structure leads to decreases in bending resistance of produced fabrics.

\section{3-5: Water vapour permeability (WVP):}

Table (2) and figure (8) shows the results of water vapour permeability test carried out on the produced samples using parameters mentioned be-

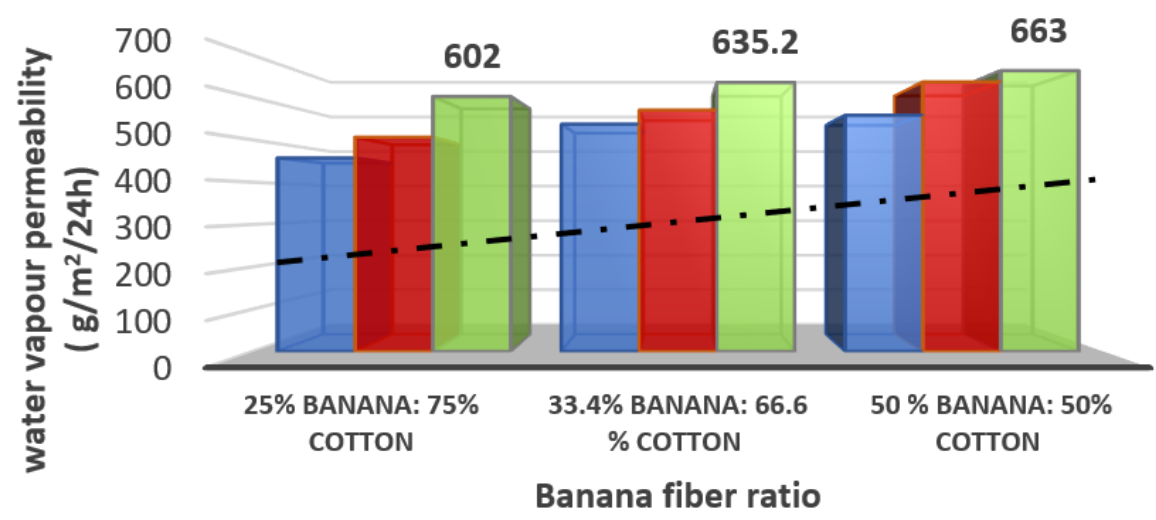

$\square$ plain $1 / 1 \quad \square$ twill $2 / 2 \quad \square$ satin 4

Fig. (10) Effect of banana fibre ratio \& weave structure on fabric water vapour permeability.

Table (7) Regression equation and quadratic coefficient for the effect of banana fibre ratio on fabric (WVP) for produced samples.

\begin{tabular}{|c|c|c|}
\hline Weave structure & Regression equation & $\mathbf{R}^{\mathbf{2}}$ \\
\hline Plain 1/1 & $\mathrm{y}=365.1 \mathrm{x}+385.41$ & 0.7596 \\
\hline Twill 2/2 & $\mathrm{y}=504.98 \mathrm{x}+388.37$ & 0.9693 \\
\hline Satin 4 & $\mathrm{y}=233.27 \mathrm{x}+549.11$ & 0.9443 \\
\hline
\end{tabular}

Where, $\mathrm{y}=$ water vapour permeability

$\mathrm{x}=$ Banana fibre ratio

\section{3-5-1: Effect of banana fiber ratio on fabric wa- ter vapour permeability:}

It can be noticed from figure (10) and tables $(2 \& 7)$ that, there is a direct relationship between water vapour permeability of produced samples and the banana fiber ratio as weft material. This is due to the diffusion rate of water vapour along the textile material depends on the porosity of the material and on the water vapor diffusivity of the fiber. Diffusivity of the material increases with the increase in moisture regain $[29,30]$. So, as the result, an increase the banana fibers percentage which have a high moisture regain (11-15\%) compared to cotton fiber $(8.5 \%)$ leads to an increase in the water va- 
pour permeability of samples which have a high concentration of banana fibers.

\section{3-5-2: Effect of weave structure on air fabric water vapour permeability:}

It is clear from figure (10) that, the weave structure satin 4 has recorded the highest rates to Water vapor permeability followed by twill $2 / 2$, plain $1 / 1$ respectively. This is owing to the water vapour diffuses through a textile structure depending on the air spaces between the warp and weft yarns [28]. So that the weave structure which has a high porosity leads to an increase in the water vapour permeability and vice versa.

\section{CONCLUSIONS}

The main purpose of this work was manufacturing a blended (banana / cotton) woven fabrics and studying effect of different parameters on comfort properties, from this work we concluded that the fabric construction with different banana fibers ratio and weave structure influenced the comfort properties of samples as; air permeability, fabric stiffness and water vapour permeability. From the results, statistical analysis and discussion concerning with the properties of produced fabrics evidently showed that:

- There is an inverse relationship between banana fiber ratio and fabric areal density, where is sample (1) with weft ratio $(25 \%$ banana: $75 \%$ cotton) and weave structure plain $1 / 1$ has scored highest rates of fabric weight compared to sample (9).

- The banana fiber ratio has a weak effect on the fabric thickness. Whilst weave structure twill $2 / 2$ has scored the high rates of fabric thickness followed by satin $4 \&$ plain $1 / 1$ respectively.

- For air permeability property, sample (9) with weft ratio (50\% banana: 50\% cotton) and satin 4 structure has recorded the highest rates of passing air through the fabric. Whilst sample (1) with weft ratio ( $25 \%$ banana: $75 \%$ cotton) and weave structure plain $1 / 1$ has recorded lowest rates of air permeability.

- There is an inverse relationship between banana fiber ratio and fabric stiffness, where is sample (1) with weft ratio (25\% banana: $75 \%$ cotton) and weave structure plain $1 / 1$ has scored highest rates of fabric stiffness compared to sample (9).

- For water vapour permeability (WVP) property, there is a direct relationship between banana fiber ratio as weft material and the (WVP) result. sample (9) with weft ratio (50\% banana: $50 \%$ cotton) and satin 4 structure has achieved the highest rates of (WVP). Whilst sample (1) with weft ratio ( $25 \%$ banana: $75 \%$ cotton) and weave structure plain $1 / 1$ has scored lowest rates of water vapour permeability.

\section{REFERENCES}

1. El-Homossani M, Gawad MA, Khalifa, F. T., Hafez S.H., "Achieving optimum thermal comfort properties for automotive seat fabrics". International of Advance Research in Science and Engineering, 4(11):424-435, 2015

2. RajKumar G., Krishnaveni V., " Influence of banana pseudostem aqueous extract on the comfort properties of cotton fabric" International Journal of Green Pharmacy, 12 (3): 621-624, 2018

3. Abu-Rous M., Dabolina I., Lapkovska E., "Fabric physical properties and clothing comfort". IOP Conf. Series: Materials Science and Engineering, 459, 2019

4. Song G., "Improving comfort in clothing", Wood head Publishing Ltd and CRC Press LLC, pp. 6066, 2011

5. A. Das, M.Ishtiaqe, "Comfort characteristics of fabrics containg twist - less and hollow fibrous assemblies in weft", journal of textile and apparel, technology and management, 3 (4), 2004

6. Shah, Hetal, B. Srinivasulu, and Subhas C. Shit., "Influence of Banana Fibre Chemical Modification on the Mechanical and Morphological Properties of Woven Banana Fabric/Unsaturated Polyester Resin Composites", Polymers from Renewable Resources 4 (2): 61-84, 2013

7. Tholkappiyan E., " A Preliminary Study for Im- 
proving the Banana Fibre Fineness using Various Chemical Treatments". Global Journal of Researches in Engineering, 16 (3): 17-22, 2016

8. Venkateshwaran, N., and A. Elayaperumal. "Banana Fiber Reinforced Polymer Composites - A Review. "Journal of Reinforced Plastics and Composites, 29(15): 2387-96, 2010

9. Amir, N., Kamal Ariff Zainal Abidin, and Faizzaty Binti Md Shiri. " Effects of Fibre Configuration on Mechanical Properties of Banana Fibre/PP/MAPP Natural Fibre Reinforced Polymer Composite." Procedia Engineering 184: 573-80, 2017

10. Pawar S., Jagtap Y., Salunke S., Jagtap V., Shinde K., Dhoka R., " Enhancing the properties of concrete by using banana fiber", Scientific Journal of Impact Factor (SJIF). 5(6): 193-199, 2018

11. Santhosh J., "Study of Properties of Banana Fiber Reinforced Composites." International Journal of Research in Engineering and Technology, 3(11): 144-50, 2014

12. K J Vishnu Vardhini, R Murugan, C Tamil Selvi, R Surjit, "Optimisation of alkali treatment of banana fibers on lignin removal" Indian Journal of Fibre \& Textile, vol. 41: pp.156-160, 2016

13. Ravi Bhatnagar, Gourav Gupta, Sachin Yadav, "A Review on Composition and Properties of Banana Fibers", International Journal of Scientific \& Engineering Research, 6(5): 49-52, 2015

14. Avunoori M., "A study on banana fiber clothing ", M.sc thesis, National institute of fashion technology, Mumbai, India: 13-30, 2017

15. Ortega, Zaida, Moisés Morón, Mario Monzón, Pere Badalló, and Rubén Paz., "Production of Banana Fiber Yarns for Technical Textile Reinforced Composites." Materials 9, no. 5: 370, 2016

16. Nazire Deniz Yilmaz, Mine Sulak, Kenan Y1lmaz \& G M Arifuzzaman Khan, " Effect of chemical treatments on physico-chemical properties of fibers from banana fruit and bunch stems " Indian Journal of Fibre \& Textile, vol. 42: pp.111-117, 2017

17. A. Z. K. Hanaa, "Study of Properties of Banana Fiber, Extracted from Egyptian trees " Journal of Architecture, Arts and Humanistic Science, 3 (10), 37-42, 2018

18. Abdel Gawad-Nehad M.A., Amin, O.A., Abd ElMoneim-Eman A. A., Abo- Sedera S. A., Vegetative growth, Productivity and Fruit Quality of Grande Naine Banana Plants as Influenced by
Feldspar and Bio-Fertilization under Sandy Soil", Middle East Journal of Agriculture Research, 6(2), 294-301, 2017

19. https://knoema.com/atlas /Egypt/topics /Agriculture /Crops-Production-Quantity -tonne /Bananas -production, (May- 2020)

20. Hafez Hawas, Y.A. Abo El amaim "Influence of Using Different Blend Ratios of Banana Fiber on the Mechanical Properties of Woven Fabrics", Journal of Architecture, Arts and Humanistic Science, In press, (Accepted date July 2020)

21. ASTM D3776 -09 "Standard Test Methods for Mass Per Unit Area (Weight) of Fabric"

22. ASTM D1777 - 96 (2015) "Standard Test Method for Thickness of Textile Materials"

23. ASTM D737 - 04 (2012) "Standard Test Method for Air Permeability of Textile Fabrics"

24. 24. ASTM D4032-08 "Standard Test Method for Stiffness of Fabric by the Circular Bend Procedure"

25. BS 7209-1990 "Standard Test Method for water vapour permeability of Fabric by cup method"

26. Menghe Miao and John H. Xin, "Engineering of High-Performance Textiles", Wood head Publishing Ltd and CRC Press LLC, pp.107-131, 2018

27. M. D. Y. Milani, D. S. Samarawickrama, G. P. C. A. Dharmasiri \& I. R. M. Kottegoda, "Study the Structure, Morphology, and Thermal Behavior of Banana Fiber and Its Charcoal Derivative from Selected Banana Varieties", Journal of Natural Fibers, 13:3, 332-342, 2016

28. Muhammad Umair, Tanveer Hussain, Khubab Shaker, Yasir Nawab, Muhammad Maqsood \& Madeha Jabbar, "Effect of woven fabric structure on the air permeability and moisture management properties", The Journal of The Textile Institute, 107(5):596-605, 2015

29. Onofrei, Elena, Ana Maria Rocha, and André Catarino. "The Influence of Knitted Fabrics' Structure on the Thermal and Moisture Management Properties." Journal of Engineered Fibers and Fabrics, 6 (4): 10-22, 2011

30. Nassar K, Abou-Taleb EM., "Effect of Selected Fabric Construction Elements on Wicking Rates of PET Fabrics." Journal of Textile Science \& Engineering,4 (3), 2014 